\title{
Pengaruh Pemberian Ekstrak Daun Pandan Wangi ( Pandanus Amarillyfolius Roxb.) Terhadap Berat Testis Dan Diamater Tubulus Mencit (Mus Musculus )
}

\author{
Lili Fajria ${ }^{\text {a }}$ \\ ${ }^{a}$ Program Studi Ilmu Keperawatan FK UNAND
}

\begin{abstract}
Pandan Wangi (Pandanus amaryllifolius Roxb) commonly used by Indonesia people. The chemical contents of pandan wangi are : Tanin, Saponin, Alkaloid, Flavonoid and colors essens (DepKes RI,1997). According to some researches on other vegetation such as star fruit (Rezano.A,2008), which found that the active ingredients have an anti-fertility effect on mice. High rate population problems in Indonesia nowadays that increased 1,3 percent per year(BPS,2007) creating a demand of a safe, effective, high reversibility contraception methods which are not influences libido and sexual activity. So, herbal medicine are one of alternatives to provide family planning method that met the requirements. Objective of this researches was to find out the influence of prescribing pandan wangi leaves extracts in depreciation of testicle mass weight and diameter of tubulus. The nature of this research was experimental research using Posttest Only Control Group Design. Research conducted in laboratory of Medical Faculty og Andalas University, start from July 25, 2008 to August 30,2008. The populaton was 24 Japanese's strain mice originted from Mathematics and Sciences Faculty of was used in analyzing with one control group. ANOVA test was used in analyzing with degree of significant was $95 \%$, and if the result are significant them it will extended with Bonferroni type Multiple Comparisons test ( Post Hoc Test) General result of this research initiates that prescribing the extracts of pandan wangi leaves have influences in depreciation of testicle mass weigh $p=0,000$, tubulus diameter $p=0,001$. The null hypothesis are rejected ( $p<0,05$ ). Meanwhile at the Bonferroni Multiple Comparrisons test found that statistically, there was no significant influences between gruops of treatment. As conclusion of this research was that active ingredients containing in pandan wangi leaves could distracts spermatogenesis process on ice in depreciation of testicle mass weight and diameter of tubulus. Extension research suggested to used different and increased prescribing dosage.
\end{abstract}

Key words : alkaloid, saponin, tanin, flavonoid, berat testis, diameter tubulus

\begin{abstract}
Abstrak : Pandan Wangi ( Pandanus amaryllifolius Roxb) merupakan tanaman yang banyak tumbuh dan digunakan oleh masyarakat Indonesia. Kandungan kimia yang terdapat dalam Daun Pandan Wangi adalah : Tanin, Saponin, Alkaloid, Flavonoid dan Zat Warna. Beberapa penelitian pada tanaman lain seperti ekstrak daun belimbing manis (Rezano.A.2008) zat-zat aktif tersebut terbukti mempunyai efek antifertilitas pada mencit. Mengingat permasalahan di Indonesia saat ini, terjadinya peningkatan jumlah penduduk yang sangat tinggi yaitu $1,3 \%$ per tahun ( BPS, 2007), maka perlu dikembangkan metoda kontrasepsi pada pria yang aman, efektif, reversibelitas tinggi dan tidak mempengaruhi seks dan libido. Untuk itu tanaman obat merupakan salah satu alternatif dapat ditemukannya metoda $\mathrm{KB}$ tersebut dan tujuan dari penelitian ini untuk mengetahui pengaruh pemberian ekstrak daun pandan wangi terhadap penurunan berat testis dan diameter tubulus mencit. Penelitian bersifat eksperimen dengan rancangan Postest only group design. Penelitian dilakukan dilaboratrium Biologi FK UNAND Padang. Populasi adalah mencit putih strain Jepang berasal dari laboratorium FMIPA UNAND dan sampel berjumlah 24 ekor dibagi atas 4 kelompok dengan 1 kelompok kontrol. Analisa dengan Uji ANOVA dengan derjat kepercayaan $95 \%$ dan jika bermakna dilanjutkan dengan Uji Multipe Comparisons (Post Hoc Test) jenis Bonferroni. Hasil penelitian secara umum didapatkan pemberian ekstrak daun pandan wangi berpengaruh terhadap penurunan berat testis $\mathrm{p}=0,000$ dan diameter tubulus $\mathrm{p}=0,001(\mathrm{p}<0,05)$. Namun pada Uji Multiple Comparisons Bonferroni didapatkan antar kelompok perlakuan belum menunjukkan pengaruh secara statistik. Kesimpulan bahwa zat aktif yang ada dalam daun pandan wangi dapat menggangu proses spermatogenesis mencit sehingga terbukti terjadinya penurunan berat testis dan diameter tubulus.Disarankan untuk dilakukan penelitian lanjutan dengan peningkatan dosis pemberian yang berbeda.
\end{abstract}

Kata kunci : alkaloid, saponin, tanin, flavonoid, berat testis, diameter tubulus 


\begin{abstract}
Indonesia merupakan negara berkembang yang mempunyai jumlah penduduk yang banyak. Menurut sensus penduduk Indonesia tahun 2005, penduduk Indonesia berjumlah 218,8 juta jiwa dengan laju pertambahan penduduk sekitar 1,3\% per tahun ( BPS,2007). Penggunaan alat kontrasepsi di kalangan pria belum membudaya seperti halnya pada kaum perempuan. Namun pemerintah berusaha keras untuk meningkatkan kesetaraan ini agar populasi penduduk Indonesia dapat kembali ditekan. Program Keluarga Berencana (KB) yang pernah sukses, beberapa tahun terakhir justru terlihat lesu darah, maka dengan ditemukan metode kontrasepsi bagi pria diharapkan program KB dapat bergairah kembali (BKKBN,2007).
\end{abstract}

Melihat kenyataan ini, tawaran ramuan tradisional sepertinya tak kalah menarik dan dinilai relatif lebih aman dan efektif. Sebenarnya penggunaan bahan tanaman untuk kontrasepsi sudah lama dilakukan oleh leluhur bangsa. Badan kesehatan dunia (WHO) justru telah membentuk tim kerja untuk mencari dan mengembangkan metode kontrasepsi untuk pengaturan kesuburan pria. Pengendalian kesuburan pria sebenarnya lebih sulit dibandingkan dengan wanita. Hal ini karena jutaan sperma yang diproduksi oleh organ reproduksi pria harus dikendalikan agar tidak membuahi ovum. Disamping itu metode kontrasepsi pria juga haruslah aman, mempunyai kinerja yang cepat dan tanpa efek samping, serta mempunyai reversibilitas yang tinggi dan tentunya juga tidak mempengaruhi seks dan libido. (Wang \& Waites, 1993)

Sebagai negara tropis Indonesia kaya akan berbagai spesies flora. Dari empat puluh ribu jenis flora yang tumbuh di dunia, terdapat tiga puluh ribu jenis diantaranya tumbuh di Indonesia dan $26 \%$ telah dibudidayakan serta sisanya masih tumbuh secara liar. Dari yang sudah dibudidayakan ( \pm 7.000 jenis), sekitar 940 jenis digunakan $\mathrm{s}$ sebagai obat tradisional (Yus,1992). Salah satu kegunaannya adalah sebagai obat kontrasepsi. Berbagai jenis tanaman telah dilaporkan mempunyai efek antifertilitas, baik terhadap hewan jantan, hewan betina dan sperma manusia secara in vitro. Winarno (1997) mengemukakan bahwa dari beberapa pustaka tercatat 74 jenis tanaman yang secara empiris digunakan oleh masyarakat di beberapa daerah untuk kontrasepsi tradisional. Menurut Agoes.A, 18 jenis diantaranya telah dibuktikan dapat menurunkan kesuburan atau antifertilitas.

Tanaman obat menurut Depkes RI yang tercantum dalam SK Menkes No.149 / SK Menkes IV / 1978 adalah tananam atau bagian tanaman yang digunakan sebagai bahan baku obat (prekursor), atau ekstrak tanaman yang dapat digunakan sebagai obat. Dari beberapa tanaman diatas ,salah satu tanaman yang diduga juga dapat dijadikan sebagai obat kontrasepsi pria dan bersifat antifertilitas karena mempunyai kandungan zat yang sama seperti Saponin, tanin, flavanoid, alkaloid, polifenol dan zat warna adalah daun pandan wangi (Pandamus amaryllifolius Roxb), (Yuniarti,titin.2008).

Dari penelusuran kepustakaan, daun pandan wangi (Pandanus amaryllifolius Roxb) mengandung tanin, saponin, alkaloid dan flavonoid. Senyawa-senyawa tersebut sudah terbukti bersifat antifertilitas. Karena itu penulis ingin mengetahui apakah pemberian ekstrak daun pandan wangi (Pandanus amaryllifolius Roxb) berpengaruh terhadap testis mencit (Mus musculus) Strain Jepang.

Tujuan dari penelitan ini adalah untuk mengetahui pengaruh pemberian ekstrak daun pandan wangi dengan konsentrasi $10 \%, 20 \%$ dan $40 \%$ terhadap penurunan berat testis dan diameter tubulus mencit jantan strain jepang.

Pandan wangi tumbuh didaerah tropis dan banyak ditanam di halaman atau di kebun. Pandan wangi juga tumbuh liar di tepi sungai, tepi rawa, dan tempat-tempat yang agak lembab, tumbuh subur dari daerah pantai sampai daerah dengan 
ketinggian 500 meter di atas permukaan laut. (Yuniarti T , 2006; Dalimartha S, 2007).

Pandan wangi dimasyarakat sudah diketahui kegunaannnya dapat mengurangi rambut rontok, menghitamkan rambut, menghilangkan ketombe,dan dapat juga digunakan untuk mengobati penyakit lemah saraf (neurastemia), tidak nafsu makan, rematik, pegal linu, sakit disertai gelisah. Adapun bagian dari pandan wangi yang sering digunakan adalah daunnya, sedangkan untuk buah, akar ,dan lain-lain belum ada penelitiannya.

Kandungan kimia yang terdapat pada daun pandan wangi adalah :Tanin, flavanoida, Saponin, Alkaloida, Polifenol dan Zat warna (Dep.kes RI,1997)sebagai berikut :

a. Flavanoid

Flavanoid adalah salah satu senyawa yang bersifat racun / aleopati, merupakan persenyawaan glocoside yang terdiri dari gula yang terikat dengan flavon. Flavonoid yang tidak ada rasanya disebut hesperidin, sedangkan limonin menyebabkan rasa pahit. Flavonoid merupakan salah satu golongan fenol alam terbesar dan golongan flavonoid mencakup banyak pigmen yang paling umum serta terdapat pada seluruh tumbuhan mulai dari fungus sampai angiospermae.

(Dinata.A, 2003) Menurut Winarno.W (1997) mengatakan bahwa flavonoid dapat menghambat enzim aromatase, yaitu enzim yang berfungsi mengkatalisi konversi androgen menjadi estrogen yang akan meningkatkan hormon testosteron. Tingginya konsentrasi testosteron akan berefek umpan balik negatif ke hipofise, yaitu tidak melepaskan FSH dan LH, sehigga akan menghambat spermatogenesis (Susetyarini.E, 2003 )

b. Saponin

Saponin adalah suatu glikosida yang mungkin ada pada banyak macam tanaman. Fungsi dalam tumbuhan tidak diketahui, mungkin sebagai bentuk penyimpanan kabohidrat, atau merupakan waste product dari metabolisme tumbuh-tumbuhan.
Kemungkinan lain adalah sebagai pelindung terhadap serangga.

Toksisitasnya mungkin karena dapat merendahkan tegangan permukaan ( surfacetension ). Dengan hidrolisa lengkap akan menghasilkan saponigen ( aglikon ) dan karbohidrat ( hexose, pentose dan saccharic acid ).

c. Tanin

Tanin merupakan polimerasi polifenol sederhana dan merupakan senyawa fenolitik larut air dengan BM 500 - 3000 yang memberikan senyawa fenol dan memiliki sifat-sifat khusus seperti presifitasi alkaloid, gelatin dan protein-protein lain.

Berdasarkan struktur kimia, tanin dapat dibedakan menjadi:

1. Tanin yang terhidrolisiskan

2. Tanin tak terhidrolisiskan/tannin terkondensasi

Menurut Winarno.W ( 1997 ) zat tanin kerjanya dapat menggumpalkan sperma, sehingga dapat mengganggu motilitas.

d. Alkaloid

Alkaloid tanaman mempunyai kemampuan mengikat tubulin, yaitu suatu protein yang menyusun mikrotubulus dengan menghambat polimerisasi protein ke dalam mikrotubulus sehingga terjadi penghancuran mikrotubulus menjadi kristal-kristal kecil. Alkaloid tanaman ini dapat pula mengantagonisir perbaikan protein sitoskeleton yang menyebabkan pembundelan mikrotubulus dan gangguan struktur mikrotubulus. Sedangkan mikrotubulus ini sangat penting untuk pergerakan sel (Wurlina, 2006).

Golongan alkaloid yang dapat mempengaruhi spermatogenesis contohnya, cucurbitasin dan Luffa acutangula Roxb. Alkaloid dapat menekan sekresi hormon reproduksi yang diperlukan untuk berlangsungnya spermatogenesis melalui mekanisme yang sudah diterangkan diatas (Wahyuni, 2006).

Mekanisme Kerja Senyawa Antifertilitas Menurut Kretser ( 1979 ) obat-obat antifertilitas pada pria dapat dikelompokkan berdasarkan

aktifitasnya menjadi 3 bagian,yaitu : 
1. Mempengaruhi sistem hormonal yang mengatur fungsi testis.

2. Menghambat spermatogenesis dengan cara mempengaruhi secara langsung fungsi testis.

3. Mempengaruhi daya fertilisasi spermatozoa

\section{Mencit Jantan ( Mus Musculus )}

Testis mempunyai fungsi ganda yaitu sebagai penghasil sel spermatozoa dan penghasil hormon androgen. Sel spermatozoa dihasilkan oleh tubulus seminiferus dan hormon androgen dihasilkan oleh sel intertisial leydig. Panjang testis mencit jantan adalah sekitar $20 \mathrm{~mm}$ dengan diameter $14 \mathrm{~mm}$ dan berat rata-rata $2-3,3$ gram.

Testis merupakan suatu kelenjar ganda oleh karena mempunyai fungsi eksokrin dan fungsi endokrin. Hasil eksokrin terutama adalah sel-sel seks, dan fungsi endokrin nya adalah menghasilkan hormon testosteron. (Leeson,1996).Hasil penelitian menunjukan bahwa selaput testis ini bukanlah sematamata suatu selaput penutup, tetapi juga bekerja sebagai suatu selaput yang dinamis, yang mampu melakukan kontraksi secara periodik. Kontraksi-kontraksi ini mungkin bekerja untuk mengatur besarnya testis dan untuk memijat sistem salurannya sehingga dapat membantu pergerakan spermatozoa ke arah luar. Dan selaput ini juga memiliki sifat semipermeabel yang punya peranan dalam beberapa aspek faal testis.

Tiap tubulus Seminiferus berjalan sangat bergelung-gelung memiliki penampang kurang lebih $0,2 \mathrm{~mm}$ dengan panjang 30-70 $\mathrm{cm}$. Pipa-pipa ini bermuara sebagai ujung-ujung akhir yang bebas atau sebagai bagian lingkaran yang mengadakan anastamosa dengan pipa-pipa lain di dalam satu lobulus atau kadang-kadang juga dengan pipa-pipa dari lobulus lain yang berdekatan (Leeson,1996). Epitelium seminiferus mengandung 2 kelompok sel yang jelas berbeda. Sel penyokong atau sel pemberi makanan dan sel-sel germinal atau sel-sel spermatogenik yang nanti akan berubah menjadi spermatozoa.

\section{METODE}

Bahan yang digunakan dalam penelitian ini adalalah ekstrak Daun Pandan Wangi. Sebagai bahan uji adalah mencit jantan (Mus musculus) strain Jepang, albino, sehat, umur 2,5 sampai 3 bulan dengan berat badan rata-rata 25-35 gram.

Metode yang digunakan dalam penelitian ini adalah metode eksperimental dengan rancangan Postest only Control Group Design. (Zainuddin,2000).

Sampel yang berjumlah 24 ekor dibagi menjadi 1 kelompok kontrol dan 3 kelompok perlakuan yang diberikan ekstrak daun pandan wangi $10 \%, 20 \%$ dan $40 \%$. Perlakuan diberikan selama 36 hari (1 siklus spermatozoa), kemudian mencit dimatikan dengan cara dislocatio cervicalis. Penelitian diawali dengan pembuatan ekstrak, penyiapan hewan coba, perlakuan, penilaian berat testis dengan timbangan elektronik pocked scale merk camry model EHA251 dan pengamatan dengan mikroskop biokuler merk Nikon Jepang.

Hasil penelitian diolah secara statistik dengan menggunakan uji One Way ANOVA dengan derajat kepercayaan $95 \%$. Jika didapatkan hasil yang bermakna, maka dilanjutkan dengan uji statistik Multiple Comparisons (Post Hoc Test) jenis Bonferroni

Daun Pandan wangi yang didapat dari Tabing kota Padang kurang lebih $5 \mathrm{~km}$ dari pantai. Daun pandan yang dimanfaatkan mulai dari pangkal daun sampai ujung daun. Panjang daun pandan yang digunakan kurang lebih $40 \mathrm{~cm}$. Pembuatan ekstrak daun pandan wangi dimulai dengan menimbang $2,5 \mathrm{~kg}$ daun pandan wangi, dicuci bersih, di iris kecil kecil dan dimaserasi dengan etanol $96 \%$ hingga terendam seluruhnya selama 5 hari. Setelah 5 hari disaring dengan kain kas. Ulangi lagi maserasi ini dengan sampel yang sama sebanyak 2 kali. Hasil maserasi didestilasi untuk mengeluarkan etanolnya. Terakhir dipekatkan dengan rotary evaporator sampai didapatkan ekstrak daun pandan wangi. Hasil ekstraksi disimpan 
dalam botol berwarna gelap agar terhindar dari cahaya.

\section{Penilaian Hasil Penelitian}

a. Penimbangan berat testis

Penimbangan berat testis dilakukan dengan menggunakan timbangan khusus yaitu Timbangan Elektronik Pocket Scale Merk Camry Model : EHA251 tahun 2005, dengan menimbang kedua testis lalu hasilnya dirata-ratakan b). Pengukuran diameter tubulus seminiferus

Pengukuran diameter tubulus seminiferus pada preparat histologis testis dengan menggunakan alat mikrometer/gratikule dilakukan dibawah mikroskop cahaya dengan pembesaran 40x10. Dipilih tubulus seminiferus yang bulat kemudian diukur diamater terjauh dan terdekat. Pengukuran dilakukan pada 40 buah tubulus seminiferus untuk tiap kelompok perlakuan dan kemudian dirata-ratakan.

\section{HASIL DAN PEMBAHASAN}

\section{a. Berat Testis}

Tabel 5.1

Rata-rata Berat (mg)Testis Mencit antara kelompok Kontrol dan Perlakuan

\begin{tabular}{lrrrrrrrr}
\hline Perlakuan & \multicolumn{9}{c}{ Kelompok $(\mathrm{mg})$} & \multicolumn{3}{c}{ Rata-rata } & SD \\
& 1 & 2 & 3 & 4 & 5 & 6 & & \\
Kontrol & 140 & 140 & 120 & 110 & 95 & 90 & 115,0 & 21.544528 \\
P 1 & 110 & 110 & 90 & 90 & 85 & 80 & 94,1 & 12.812754 \\
P 2 & 90 & 80 & 80 & 75 & 70 & 65 & 76,6 & 8.755950 \\
P 3 & 85 & 80 & 70 & 70 & 60 & 50 & 69,1 & 12.812754 \\
\hline
\end{tabular}

Dari tabel 5.1 diatas dapat dilihat rata-rata berat testis pada kontrol adalah $115 \mathrm{mg}$, sedangkan pada kelompok perlakuan berat testis mengalami penurunan yaitu $\mathrm{P} 1$ ratarata $94.5 \mathrm{mg}, \mathrm{P} 2=76.6 \mathrm{mg}$ dan $\mathrm{P} 3=69.1$ mg. Pada Uji ANOVA juga menunjukkan pengaruh pemberian ekstrak daun pandan wangi secara signifikan..

Oleh karena itu uji statistik dilanjutkan dengan uji Multiple Comparisons ( Post hoc Test ) jenis Bonferroni, dan hasilnya dapat dilihat pada tabel dibawah ini

Tabel 5.2

Hasil Uji Statistik Multiple Comparrison Bonferroni Berat Testis antara kelompokKontrol dengan Perlakuan

\begin{tabular}{ccccc}
\hline Perlakuan & Kontrol & P.1 & P.2 & P.3 \\
\hline Kontrol & - & - & - & - \\
P.1 & 0,115 & - & - & - \\
P.2 & $0,001^{*}$ & 0,318 & - & - \\
P.3 & $0.000^{*}$ & $0,049 *$ & 1,000 & - \\
\hline
\end{tabular}


Dari tabel 5.2 diatas dapat diketahui bahwa antara kelompok kontrol dengan kelompok perlakuan dengan konsentrasi 10 $\%$ belum menunjukan pengaruh penurunan B. Diameter tubulus seminiferus berat testis secara bermakna $(\mathrm{p}<0,05)$ dan baru pada konsentrasi $20 \%$ dan $40 \%$ (p < 0,05 ) terlihat pengaruhnya secara signifikan.

Tabel 5.3

Rata-rata Diameter ( $\mu \mathrm{m})$ Tubuli Seminiferus Mencit antara kelompok Kontrol dengan Perlakuan

\begin{tabular}{|c|c|c|c|c|c|c|c|c|}
\hline \multirow[t]{2}{*}{ Perlakuan } & \multicolumn{6}{|c|}{ Kelompok } & \multirow[t]{2}{*}{ Rata-rata } & \multirow[t]{2}{*}{ SD } \\
\hline & 1 & 2 & 3 & 4 & 5 & 6 & & \\
\hline Kontrol & 83 & 82 & 82 & 82 & 79 & 77 & 80,8 & 2.31661 \\
\hline P.1 & 80 & 77 & 75 & 71 & 71 & 69 & 73,8 & 4.21505 \\
\hline P. 2 & 78 & 75 & 75 & 74 & 70 & 68 & 73,3 & 3.66970 \\
\hline P.3 & 76 & 74 & 74 & 73 & 72 & 68 & 72,8 & 2.71416 \\
\hline
\end{tabular}

Dari tabel 5.3 dapat dilihat bahwa rata-rata diameter tubulus seminiferus kontrol adalah $80.8 \mu \mathrm{m}$, sedangkan pada kelompok perlakuan mengalami penurunan yaitu rata-rata P.1 $=73.8 \mu \mathrm{m}, \mathrm{P} .2=73.3 \mu \mathrm{m}$ dan P.3 $=72.8 \mu \mathrm{m}$.

Dan dari Uji ANOVA menunjukkan pengaruh yang signifikan pada pemberian ekstrak daun pandan wangi dengan konsentrasi yang berbeda.

Selanjutnya untuk melihat kemaknaan secara statistik antara kelompok kontrol dengan kelompok perlakuan dilanjutkan dengan uji Multiple Comparisons ( Post hoc Test ) jenis Bonferroni, dan hasilnya dapat dilihat pada tabel dibawah ini :

Tabel 5.4.

Hasil Uji Statistik Multiple Comparison Bonferroni Diameter Tubuli Seminiferus Mencit antara Kontrol denganPerlakuan

\begin{tabular}{ccccc}
\hline Perlakuan & Kontrol & P.1 & P.2 & P.3 \\
\hline Kontrol & - & - & - & - \\
P.1 & $0,009^{*}$ & - & - & - \\
P.2 & $0,005^{*}$ & 1,000 & - & - \\
P.3 & $0,003 *$ & 1,000 & 1,000 & - \\
\hline
\end{tabular}

Dari tabel 5.4 diatas dapat dilihat bahwa antara kelompok kontrol dengan kelompok perlakuan menunjukan pengaruh ekstrak pandan daun wangi terhadap penurunan diameter tubulus seminiferus secara bermakna $(\mathrm{p}<0,05)$ pada konsentrasi berbeda dan penurunannya dapat dilihat sesuai dengan besarnya konsentrasi yang diberikan.. Namun penurunan diameter tubulus seminiferus tidak menunjukkan pengaruh yang bermakna secara statistik ( $\mathrm{p}$ $>0,05)$ antar kelompok perlakuan.

\section{Pembahasan}


1. Berat Testis

Hasil penelitian terhadap berat testis mencit, didapatkan bahwa pemberian ekstrak daun pandan wangi (Pandanus amaryllifolius Roxb) menunjukkan penurunan rata-rata berat testis dibandingkan dengan kontrol. Dengan uji One Way ANOVA didapatkan perbedaan yang signifikan antara kelompok perlakuan dengan kontrol. Analisa dilanjutkan dengan uji Multiple Comparison (Post hoc test) Bonferroni. Didapatkan hasil bahwa pada konsentrasi $20 \%$ (P2) dan konsentrasi $40 \quad \% \quad$ (P3) baru didapatkan perbedaan yang signifikan $(\mathrm{p}<0,05)$

Penurunan berat testis terseut diduga akibat alkaloid tanaman mempunyai kemampuan mengikat tubulin, yaitu suatu protein yang menyusun mikrotubulus dengan cara menghambat polimerisasi protein ke dalam mikrotubulus sehingga terjadi penghancuran mikrotubulus menjadi kristal - kristal kecil. Disamping itu alkaloid dapat mengantagonisir perbaikan protein sitoskeleton yang menyebabkan pembundelan mikrotubulus dan gangguan struktur mikrotubulus. Sehingga keadaan ini menyebabkan perubahan pada testis, dimana perubahan tersebut akan mengganggu fungsi testis untuk tidak dihasilkan sel-sel seks dan hormon yang berperan pada proses spermatogenesis. Akibat terjadinya penurunan sel-sel dan penurunan hormon dalam testis akan mengakibatkan perubahan dalam bentuk testis dengan terjadinya pengecilan yang dapat diukur dengan berkurangnya berat testis dan diameter tubuli seminiferus.

$$
\text { Saponin juga menurunkan }
$$

permeabilitas membran sel. Permeabilitas membran yang rendah memungkinkan cairan dan elektrolit banyak masuk ke dalam sel. Sel menjadi bengkak dan lisis sehingga sel menjadi mati. Selain saponin, alkaloid juga merusak struktur membran sel . Kerusakan membran sel menyebabkan transportasi nutrisi sel terganggu (Santoso, 2008). Sel akan mengalami gangguan metabolisme dan bisa menyebabkan kematian sel. Apabila hal ini terjadi pada tubuli seminiferi, maka akan mempengaruhi struktur/bentuk testis sehingga menyebabkan penurunan berat testis.

Saponin dan alkaloid merupakan bahan baku hormon steroid. Diduga senyawa ini ikut jalur biosintesis hormon steroid, sehingga terbentuk senyawa yang strukturnya mirip dengan testosteron. Senyawa ini bersifat anti testosteron, berikatan dengan reseptor testosteron pada tubuli seminiferi sehingga testosteron tidak berfungsi (Wahyuni, 2006), menyebakan gangguan spermatogenesis.

\section{Diameter Tubuli Seminiferi}

Hasil penelitian terhadap diameter tubuli seminiferi adalah terjadi penurunan rata-rata terjadi pada diameter tubuli seminiferi. Dari uji ANOVA diketahui terdapat pengaruh yang bermakna antara kelompok kontrol dengan kelompok perlakuan terhadap penurunan rata-rata diameter tubuli seminiferus $(\mathrm{p}<0,05)$. Analisa dilanjutkan dengan uji Multiple Comparison (Post hoc test) Bonferroni. Didapatkan hasil bahwa P1, P.2 dan P.3 menunjukkan perbedaan yang signifikan terhadap kontrol. Perbedaan P.2 dan P.3 signifikan terhadap P.1, dan P.3 memperlihatkan perbedaan yang signifikan terhadap P.2.

Tubulus seminiferus diliputi oleh suatu epitelium khusus yang kompleks, suatu epitelium berlapis kuboid yang berubah-rubah. Epitelium ini duduk pada suatu lamina basalis pipih, yang pada bagian luar diliputi oleh suatu jaringan ikat khusus, yang mengandung banyak serabut jaringan ikat, fibroblas pipih dan beberapa sel otot polos. Epitelium seminiferus mengandung 2 kelompok sel yang jelas berbeda. Sel penyokong atau sel pemberi makanan dan sel-sel germinal atau sel-sel spermatogenik yang nanti akan berubah menjadi spermatozoa.

Alkaloid dan Flavanoid menyebabkan gangguan pada membran sel dengan cara merubah komponen penyusun membran dan akibat perubahan tersebut mengakibatkan proses fisiologis pada membran terganggu, yakni gangguan pada transportasi nutrisi sel dan proses 
pembentukan energi terganggu serta menyebabkan kematian pada sel. Selain itu diketahui bahwa Alkaloid dapat menghambat sintesis rRNA pada embrio dengan cara menghambat sintesa prostein dan mencegah polimerisasi DNA serta menghambat transkripsi DNA sel embrio ( Wurlina ,2008)

Akibat gangguan pada mikrotubulus tersebut mengakibatkan perubahan pada bentuk tubulus dengan mengecilnya diameter tubulus, seperti yang dibuktikn pada penelitian ini.

\section{KESIMPULAN DAN SARAN}

Dari penelitian ini dapat disimpulkan bahwa pemberian ekstrak daun pandan wangi (Pandanus amaryllifolius Roxb.) dengan konsentrasi 10\%, 20\% dan 40\% dapat menurunkan rata - rata berat testis dan diameter tubulus mencit (Mus musculus) strain Jepang pada konsentrasi 20 $\%$

Disarankan kepada peneliti selanjutnya untuk untuk meneliti kadar tanin, saponin, alkaloid dan flavonoid yang terkandung dalam daun pandan wangi. Disamping itu disarankan juga untuk mencari dosis optimal yang dapat menurunkan fertilitas spermatozoa mencit.

\section{DAFTAR PUSTAKA}

----------. 2008. Serba Serbi Kontrasepsi. Dari http://www.medicastore.com/oc/ serbaserbi.htm.

Cinthya Site. Pandan Wangi. Dari http://inyu.multiply.com/journal/item/ 6

Dalimartha Setiawan, 2007. Atlas Tumbuhan Obat Indonesia jilid 1. Trubus Agriwijaya: 103 - 106.

Dixit VP; Khana P; Bhargava SK, 1978. Effect of Momordica charantia, L Fruit Extract on Testicular Function Dog. Planta Medica of the Medicine Plant Research 34; 280 - 286.

Elliason R, 1973. Parameter of Male Fertility. Dalam Hafe \& Evants Ed. Human Reproduction; Conception \&
Contraception. London; Harper \& Row Publisher: 37 - 49.

Elliason R, 1977. Supravital Staining of Human Spermatozoa. Fertil Steril 28. 1257 - 1264.

Etri.Y.2008. Pengaruh Pemberian efinefrin terhadap sel spermatogenik mencit.

Farida Lia, 2008. Pengaruh Pemberian Infusa Buah Terung Tukak (Solanum torvum Swartz) terhadap Kecepatan Spermatozoa Mencit (Mus musculus). PIT PANDI XVII - PERSANDI III. Jogjakarta.

Hariana Arief, 2007. Tumbuhan Obat \& Khasiatnya, seri 2. Jakarta. Penebar Swadana: $163-165$

Junquiera. 2005. Basic Histologi, E.G.C

Kloppenburg J - Verstegh, 2006. Tanaman Berkhasiat Indonesia vol 1. Bogor. IPB Press: 129 - 130.

Moeloek N, 1990. Kontrasepsi Pria: Masa Kini dan Masa yang Akan Datang. Medika 2 (16): 151 - 159.

Nurliani A, Rusmiati, Santoso HB. Perkembangan Sel Spermatogenik Mencit (Mus musculus L.) Setelah Pemberian Ekstrak Kulit Kayu Durian (Durio zibethinusMurr.). dari http://journal.discoveryindonesia.com/ index.php/hayati/article/view PDFInterstitial/56/64

Oentung, S .(2000). Simposium Kesehatan Reproduksi Pria.Bagian Biologi Fakultas Kedokteran Universitas Indonesia.

(http:/www /pd.persi co.id. diakses 25 Maret 2008)

Purwaningsih E, Sumiarsih T, 1998. Efek Spermatisida Biji Oyong (Luffa acutangula Roxb) terhadap Motilitas dan Viabilitas Sperma In Vitro. Jurnal Kedokteran Yarsi. September 1998 Vol. 6 No. 3.

Rugh R. 1997. The Mouse Its Reproduction and Development. Mineapolis.Burgess.

Rezano Andri, 2008. Efek Pemberian Infusa Daun Belimbing Manis (Averrhoe carambola L) terhadap Jumlah Spermatozoa Mencit (Mus musculus). 
PIT PANDI XVII - PERSANDI III. Jogjakarta.

Sarifudin, 2008. Efek Infusa Herbal Bandotan (Ageratum conyziodes Linn) Terhadap Kecepatan Spermatozoa Mencit (Mus musculus). PIT PANDI XVII - PERSANDI III. Jogjakarta.

Setiawati A. 1982. Penggunaan dan Penggunasalahan Statistik dalam Percobaan Klinik. Cermin Dunia Kedokteran 25: 10 - 21.

Sudarsono, 2008. Pengaruh Pemberian Infusa Rimpang Temu Lawak (Curcuma xanthorrhiza Roxb) terhadap Kecepatan Spermatozoa Mencit (Mus musculus). PIT PANDI XVII - PERSANDI III. Jogjakarta.

Susanna Dewi; Rahman; Pawenang EY. Potensi Daun Pandan Wangi untuk Membunuh Larva Nyamuk Aedes Aegypti.

Dari http://www.ekologi.litbang.depkes.go. id/data/vol\%202/DSusana2 2.pdgoogle .

Wang C; Waites GMH, 1993. Research Strategy of the World Health
Organization Task Force on Methodes for the Regulation og Male Fertility and Need for Sperm Function Assays. Dalam Oshima \& Hendry Ed.Current topics in Andrology. Japan Soociety of Andrology. WHO, 1988

Wurlina. Pengaruh Antimikosis Ekstrak Achyranthes Aspera Linn Pada Pembelahan Sel Embrio (Cleavage). Dari

http://.litbang.depkes.go.id/lokaciami s/artikel/lalat-arda.htm.

Winarno M.W, Sundari Dian.1997. Informasi Tanaman Obat untuk Kontrasepsi Tradisional. Cermin Dunia Kedokteran No. 120.

Yuniarti Titin, 2006. Ensiklopedia Tanaman Obat Tradisional. Yogyakarta. Med Press: $290-293$.

Yatim wildan, 1996. Biologi Modern Histologi, Bandung: Tarsito: 231 248

Zainuddin.M (2000). Metodologi Penelitian. Universitas Airlangga Press. Surabaya. 